\title{
Late Holocene Vegetation and Environmental Changes of Coastal Lowlands in Northern Iran: Possible Role of Climate, Human Impact and Caspian Sea Level Fluctuations
}

Fang Gu ( $\sim$ Fang.Gu@biologie.uni-goettingen.de )

University of Gottingen: Georg-August-Universitat Gottingen

Kamaleddin Alizadeh

University of Gottingen: Georg-August-Universitat Gottingen

Hermann Behling

University of Gottingen: Georg-August-Universitat Gottingen

\section{Research Article}

Keywords: Northern Iran, coastal wetlands, Hyrcanian forest, climate change, human impact, Caspian Sea level

Posted Date: February 15th, 2021

DOl: https://doi.org/10.21203/rs.3.rs-157366/v1

License: (c) (1) This work is licensed under a Creative Commons Attribution 4.0 International License.

Read Full License 
1 Late Holocene vegetation and environmental changes of coastal lowlands in northern Iran: possible role of climate, human impact and Caspian Sea level fluctuations

\author{
Fang Gu${ }^{1 *}$, Kamaleddin Alizadeh ${ }^{1}$, Hermann Behling ${ }^{1}$
}

To be submitted to Wetlands

\title{
Abstract
}

Coastal forests and wetlands play an important role in supporting biological diversity, protecting the hinterlands and shorelines along the continental margins from erosion, as well as for contributing to carbon and freshwater storage. To reconstruct late Holocene vegetation and environmental dynamics in the coastal lowlands in northern Iran and detect the possible role of climate, human impact and Caspian Sea (CS) level fluctuation on coastal ecosystems, a multi-proxy analysis including pollen, spores, non-pollen palynomorphs, macro-charcoal and Xray fluorescence analysis, have been applied on the radiocarbon dated sediment cores from the Eynak (EYK) lagoon further inland and Bibi Heybat (BBH) alder swamp near the coast. Open wetlands covered relatively large areas since the recorded period (1450 cal yr BP). At BBH larger areas of open vegetation occurred and alder forests covered only small areas that expanded during the late Little Ice Age (1650-1850 AD) and were most abundant during the last about 100 years. Further inland at EYK, areas of alder and mixed broad-leaved Hyrcanian forest were larger. Alder forest in general expanded since $600 \mathrm{cal} \mathrm{yr} \mathrm{BP.} \mathrm{In} \mathrm{the} \mathrm{last} 170$ years, alder forest areas and wetlands declined strongly, due to deforestation and strong human activities. The intensity of human impact, climatic fluctuations and changes in CS level were the most important factors controlling the dynamics of the northern Iranian coastal vegetation.

Keywords Northern Iran, coastal wetlands, Hyrcanian forest, climate change, human impact, Caspian Sea level

\section{Introduction}

Coastal forests and wetlands play an important role in providing species-rich habitats for supporting biological diversity, as well as for contributing to carbon and freshwater storage (Barbier et al. 2011). Furthermore, coastal vegetation serves as "security guards" to protect the shorelines along the continental margins from erosion. Wetland ecosystems can also create a natural corridor to provide the pathway for their migration (Lindshield et al. 2016; Nasrollahzadeh et al. 2012).

Along the coastal region of the southern Caspian Sea (CS), the Hyrcanian forest has been recognized as a hotspot of biodiversity, important refugia, and last relicts of broad-leaved deciduous forests. This temperate forests covered the temperate zones of the northern hemisphere and survived from extreme climatic conditions during 
the coast to the highland of the Alborz and Talysh Mountains. Despite the importance to understand the vegetation and environmental dynamics of the coastal lowlands in northern Iran, only a few studies are available. The coastal wetlands may have experienced marked changes following changes in the temperature, rainfall regime, and CS level changes through space and time (e.g. Shariatpanahi et al. 2013).

Two pollen records from Anzali and Amirkola lagoons (Fig. 1; Leroy et al. 2011) cover palaeoenvironmental changes during the last four centuries, indicating that brackish water has influenced the coastal plain of CS during the LIA, due to its high stands. Previous study also suggests that the CS level changed markedly in the past. It is noted that before $1500 \mathrm{cal} \mathrm{yr} \mathrm{BP}$, the CS level decreased and dropped to the lowest level of $42 \mathrm{~m}$ b.s.l. (Hoogendooren et al. 2005). While during the Little Ice Age (LIA), the sea level increased up to $21 \mathrm{~m}$ b.s.l. (Beni et al. 2013). The record Amirkola indicates that a dense alder forest (mainly by Alnus glutionosa) covered the lowland since ca. $1620 \mathrm{AD}$. The dense alder wetland forest has been temporarily disturbed by fire before it was converted by the expansion of rice fields from 1720 to 1800 AD. The vegetation was more stable in the Anzali record compared with the Amirkola record. From 1700 to 1830 AD, brackish water from the CS to the wetlands has been detected (Leroy et al. 2011).

An approximately 650-year old sediment core, recovered from the Langarud wetland (Fig. 1), located $10 \mathrm{~km}$ inland (Haghani et al. 2016), indicates that after the brackish water incursion at the early LIA (LIA is from 1350 to $1850 \mathrm{AD}$; Mann et al. 2009), the alder swamp, which is very sensitive to salt, became extensively damaged and the salty soils became unsuitable for agriculture activities.

Sedimentological studies also suggest that the CS plays a predominant role in the sediment deposition in the region of the Sefid Rud delta (Fig. 1) with sediments composed by both, marine CS and terrestrial origin (Kazanc1 et al. 2004). That coastal ecosystems have been influenced by the CS water level fluctuations has been recorded by modern satellite monitor technology in the southwestern CS of Gorgan bay and Gomishan lagoon (Jeihouni et al. 2019). However, the past CS water level fluctuations and the impact on the coastal region during the historical period still need to rely on the proxy-based reconstructions. Nowadays, the increasing human activities, changing the coastal landscape by conversion to farmland, as well as constructions and pollution, the wetland ecosystems have been heavily disturbed, destroyed and threatened (Barbier et al. 2011; Lotze et al, 2006; Worm et al. 2006; Halpen et al. 2008; Gedan et al. 2009). A multiproxy record from the wetlands near the slopes of Paeen Zarbijar Mountain (Fig. 1), showed that the anthropogenic impact by constructions and fire became frequent during the last 100 years and played an important role in the decline of the Hyrcanian forest (Gu et al. 2021).

In order to reconstruct and to understand the development of the wetlands and coastal vegetation in the lowlands of northern Iran, including its changes, regarding the dynamics of the CS, climate change, as well as the human impact on wetlands and lagoons, a multi-proxy analysis, including pollen, spores, non-pollen palynomorphs (NPPs), loss on ignition (LOI), macro-charcoal and X-ray fluorescence (XRF) analysis has been conducted on sediment cores from two new locations.

\section{Study area}

The two study sites are the Eynak lagoon in Rasht further inland $\left(37^{\circ} 16^{\prime} 36.87^{\prime \prime} \mathrm{N}, 49^{\circ} 32^{\prime} 17.66^{\prime \prime} \mathrm{E}, 5 \mathrm{~m}\right.$ a.s.l.), and Bibi Heybat alder swamp near the coast (37 $21^{\prime} 10.83^{\prime \prime} \mathrm{N}, 49^{\circ} 57^{\prime} 45.94 " \mathrm{E}, 15 \mathrm{~m}$ b.s.l.) in the Gilan province of northern Iran (Fig. 1). The topography of the study area is shaped by the mountain system of the Talesh Mountains 
and western Alborz Mountains to the south, with steep slopes, and the lowland coastal plains adjacent to CS in the north. During the Holocene a set of coastal wetlands, alluvial fans, deltas, coastal lagoons have been formed.

83 Several rivers and streams originate from the northern slopes of the Talesh Mountains and western Alborz

84 Mountains. Among them, the largest is Sefidrud which is ca. $670 \mathrm{~km}$ long and formed a large delta in the coastal region (Krasnozhon et al. 1999). In 1962, the Manjil Dam was built to prevent flooding and to increase the rice production in the delta region.

87

\section{Climate}

89 The climate of the study area in the Gilan province has a generally humid climate with a Mediterranean climate with hot, dry summers and cool, wet winters (Köppen 1936). Due to the influence of the onshore winds from the Siberian High and the humid air mass, transported from the western Mediterranean Sea, Black Sea, and Atlantic Ocean (Heydarizad et al. 2019; Persoju et al. 2019), the maximum annual rainfall has been recorded in the southwestern coast with $1900 \mathrm{~mm}$ compared to the average annual rainfall of $1506 \mathrm{~mm}$. The highest rainfall is between September and December, while between April and July less rainfall occurs. The average annual temperature in the Gilan province is $15.8^{\circ} \mathrm{C}$ and ranges from the lowest average temperature of $4.1^{\circ} \mathrm{C}$ in February to the highest of $27.8{ }^{\circ} \mathrm{C}$ in August (https://www.worlddata.info/asia/iran/climate-gilan.php; Ravanbakhs et al. 2013). Mountains above $1500 \mathrm{~m}$ can receive snow during the winter.

\section{Vegetation and human impact}

99 Due to the soil and the hydrological conditions, diverse vegetation occurs near the study area. The modern

100 Hyrcanian forests in the lowland are mainly composed of alder swamps with the dominance of Alnus glutinosa spp. barbata at a lower elevation, while broad-leaved forests with Parrotia persica, Pterocarya fraxinifolia,

102 Carpinus betulus, Zelkova carpinifolia, Quercus castaneifolia are distributed at higher elevated areas with relatively good drained soils (Djamali et al. 2009).

104 The observed local vegetation near the Eynak lagoon wetland in the western part of the city of Rasht includes 105 species of Ulmus carpinifolia and Zelkova carpinifolia. Phragmites australis densely covers the wetlands and its 106 margins. Also Malva, Amaranthaceae and different Poaceae species are distributed around the wetland. Recently, 107 the exotic plant Azolla has seriously invaded the wetland and is becoming an environmental concern.

108 Based on the archaeological record from Yarshalman cave, early human settlements since the Pleistocene in Gilan 109 was mainly located in high-elevated regions, (Biglari and Jahani 2011). Contrarily, the current human settlements 110 are highly restricted to the coastal lowland, especially in the study area of the Eynak lagoon in Rasht.

111 Nowadays, due to the uncontrolled exploitation and agricultural developments, vast forest areas in the lowlands 112 of northern Iran have been destroyed, converted to rice fields and cultivation land (e.g. olive trees, citrus, tangerine, 113 lemon) in the coastal plains.

\section{Methods}

\section{Coring and dating}

117 The sediment core from the Eynak (EYK) lagoon is $300 \mathrm{~cm}$ long and was collected with a Livingstone corer. Four 118 small one $\mathrm{cm}$ thick bulk samples $\left(2 \mathrm{~cm}^{3}\right)$ have been taken for the Accelerator Mass Spectrometry (AMS) 119 radiocarbon dating. The sediment core from the Bibi Heybat $(\mathrm{BBH})$ alder swamp is $116 \mathrm{~cm}$ long, taken with a 
120 Russian peat corer. Three small bulk samples have been also taken for AMS dating. All dates have been calibrated with Clam package in the R-Studio platform (RStudio Team, 2015).

124 Pollen, spores, and non-pollen palynomorphs (NPPs) have been analyzed to reconstruct past vegetation, climatic, 125 palaeoenvironmental changes as well as anthropogenic impacts on the ecosystems. In total 39 subsamples of 1 $126 \mathrm{~cm}^{3}$ volume were taken along the EYK core and 23 subsamples along the BBH core, respectively. Before processing, one tablet with exotic Lycopodium (containing 9666 +/- 212 spores) was added for pollen concentration and influx calculations. The subsamples were sieved through $120 \mu \mathrm{m}$ metal mesh to get rid of large particles. Standard analytical techniques (Faegri and Iversen, 1989) were applied for pollen analysis. $\mathrm{HCl}(\sim 10 \%)$ was added to remove the calcareous and cold HF $(\sim 40 \%)$ treatment was applied to remove the siliceous content of the subsamples. Pollen, spores and NPPs were concentrated by sieving the concentrate through a $10 \mu \mathrm{m}$ nylon mesh. The pollen identification was performed using published pollen morphological literature (Beug 2004; Tang et al. 2016), and the reference collection of the Department of Palynology and Climate Dynamics. Most of the samples were counted up to 300 pollen grains, while for the upper $56 \mathrm{~cm}$ section of the EYK core and whole BBH core, due to the low pollen content, at least up to 200 grains were counted. Fern spores and selected NPPs were counted and grouped as well. Pollen taxa were grouped as trees/shrubs, anthropogenic indicators (mostly cultivated plants), herbs, and wetland taxa. For percentage calculation, the pollen sum includes trees/shrubs, herbs and wetland (aquatic) taxa. Wetland taxa were included in the pollen sum as we want to illustrate the wetland dynamics in context of the other vegetation groups in space and time. Poaceae $(>40 \mu \mathrm{m})$, Juglans and Vitis are selected as anthropogenic indicator taxa. Plantago lanceolata is frequently used to indicate human disturbance in the landscape (Stewart 1996), and is here included as well. Poaceae pollen grains larger than $40 \mu \mathrm{m}$ with a large pore and thick annulus in this region are considered as Oryza type, which can be originated from the cereal cultivation in Southeast Asia (Liu et al. 2007; Qiu et al. 2014). The lowland of the study area is nowadays subject to rice cultivation (Oryza sativa L.) (e.g. Bahmaniar et al. 2007). The percentage of fern spores and NPPs were calculated on base of the pollen sum. Data are illustrated by TILIA and TILIAGRAPH; CONISS cluster analysis of the taxa which were included in the pollen sum was used for the zonation of the pollen diagram (Grimm 1987).

\section{Macro-charcoal analysis}

149 The macro-charcoal analysis was performed to examine past fire history in the study area. In total, 150 subsamples

150 were taken from the EYK core at $2 \mathrm{~cm}$ intervals with a volume of $1 \mathrm{~cm}^{3}$. All samples were processed with $10 \%$

$151 \mathrm{KOH}$ and $6 \%$ hydrogen peroxide $\left(\mathrm{H}_{2} \mathrm{O}_{2}\right)$ to digest and bleach organic material in the sediment samples (Stevenson 152 and Haberle 2005). Macro-charred particles (>125 $\mu \mathrm{m}$ ) were concentrated through wet sieving with low water 153 pressure. Charred fragments were counted under a binocular dissecting microscope. Macro-charcoal particles are 154 considered from local fires. Therefore, usually, the peaks of macro-charcoal are commonly used to track the local 155 individual fire event (Higuera et al. 2011). Charcoal data were analyzed by the program CharAnalysis version 1.1 to detect past fire events in the study area (Higuera et al. 2009).

\section{$157 \quad \mathrm{X}$-ray fluorescence analysis}

158 To analyze the geochemical contents in the sediment core EYK, a high spatial resolution non-destructive X-ray 159 fluorescence (XRF) of major elements with ITRAX XRF core scanner (Mo tube at 45kV, $25 \mathrm{~mA}$, 5s exposer time) 
160 was conducted at the Institute of Geography, University of Bremen (Croudace et al. 2006; Lutz and Pernicka

161 1996). Compositional variations were measured at a step size of $2 \mathrm{~mm}$. In order to detected changes of the organic 162 and carbonate content in the sediment, the ratios of inc/coh, $\mathrm{Ca} / \mathrm{Ti}$, and $\mathrm{Ca} / \mathrm{Fe}$ has been selected (Davis et al. 2015).

\section{Loss on ignition (LOI) analysis}

165 To determine the carbonate and organic content in the EYK core, a standard LOI analysis procedure was applied

166 (Bengtsson and Enell 1986; Dean 1974; Heiri et al. 2011). In total 40 subsamples with a volume of $1 \mathrm{~cm}^{3}$ sediment 167 have been taken along the core. The wet weighted samples were dried up to $105{ }^{\circ} \mathrm{C}$ in a muffle furnace for 24 168 hours. After cooling down to room temperature, the weight of the dried material was measured. Then the dried samples were heated in the furnace up to $550^{\circ} \mathrm{C}$ and then burned for 4 hours and after cooling measured again. In the end, the weight was measured again after furnace heating and burning up to $950{ }^{\circ} \mathrm{C}$. The organic $\left(550{ }^{\circ} \mathrm{C}\right)$ and carbonate $\left(950{ }^{\circ} \mathrm{C}\right)$ content with LOI measurement was calculated using the following equation respectively : $\mathrm{LOI}_{550}{ }^{\circ} \mathrm{C}=\left(\left(\mathrm{DW}_{105^{\circ} \mathrm{C}}-\mathrm{DW}_{550^{\circ} \mathrm{C}}\right) / \mathrm{DW}_{105^{\circ} \mathrm{C}}\right) * 100 ; \mathrm{LOI}_{950^{\circ} \mathrm{C}}=\left(\left(\mathrm{DW}_{550^{\circ} \mathrm{C}}-\mathrm{DW}_{950^{\circ} \mathrm{C}}\right) / \mathrm{DW}_{105^{\circ} \mathrm{C}}\right) * 100$.

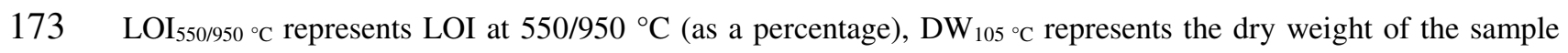
before combustion, and $\mathrm{DW}_{550}{ }^{\circ} \mathrm{C}$ the dry weight of the sample after heating to $550{ }^{\circ} \mathrm{C}$.

175

\section{Results from the Enayk lagoon sediment core}

\section{Stratigraphy and chronology}

178 For the stratigraphy of the EYK sediment core (Fig. 4), four markedly different depositions can be visually

179 identified. The bottom section of the sediment core from 300 to $110 \mathrm{~cm}$ core depth is formed by compact brownish 180 clay. The middle section from 110 to $50 \mathrm{~cm}$ is characterized by dark/black organic layers with root remains. 181 Between 50 and $38 \mathrm{~cm}$ the sediments are composed of a light brownish layer. The upper $38 \mathrm{~cm}$ is marked by dark greenish silt with dark undecomposed organic matter and plant remains. There are no sedimentary gaps that can

183 be visibly identified in the sediment core. The age-depth model is based on four radiocarbon dates (Table 1, Fig.

184 2a), with an age at the core bottom at $300 \mathrm{~cm}$ with ca. $800 \mathrm{cal} \mathrm{yr}$ BP. Based on this age-depth model, the age of the EYK pollen zones have been calculated.

\section{Pollen analytical and macro-charcoal results}

188 According to the CONISS cluster analysis, three pollen zones (Zone EYK-I, EYK-II, EYK-III) and three subzones of Zone EYK-I (Ia, Ib, Ic) can be recognized (Fig. 4).

190 Zone EYK-I (300-132 cm, ca. 800-200 cal yr BP; ca. 1150 to 1750 AD with subzone EYK-Ia (300-228 cm, 191 ca. 800-600 cal yr BP; ca. 1150 to 1350 AD), is characterized by a relatively stable pollen composition (Fig. 3). 192 Tree and shrub pollen is represented by the dominance of Alnus, followed by lower values of Carpinus betulus, 193 Fagus, Zelkova/Ulmus, Buxus and Quercus (Fig. 3). Anthropogenic indicators are mainly represented by Juglans, 194 whereas Vitis were encountered only sporadically. Cultivated herbs are mainly represented by rather high values of Poaceae pollen larger than $40 \mu \mathrm{m}$, which was attributed to Oryza sativa (see methods). Plantago lanceolata 196 pollen occur as well. Herb pollen, which is not so frequent, includes Poaceae (<40 $\mu \mathrm{m})$, Urtica, and Artemisia. 197 Wetland taxa are well represented, mainly by Cyperus and with lower values of other Cyperaceae, Ludwigia, 198 Typha latifolia type, and Myriophyllum (Fig. 3). Fern spores have low percentages. Non-pollen palynomorphs 199 (NPPs) are mainly represented by the green algae Pediastrum and a few single dinocysts (Fig. 4). At the beginning 
200 of the record occurs a prominent peak of macro-charcoal, followed by relatively frequent macro-charcoal particles

201 in this subzone compared to the following subzone (Fig. 5). In subzone EYK-Ib (228-156 cm, ca. 600-300 cal yr BP; ca. 1350 to 1650 AD), Alnus pollen steadily increases and culminates close to the upper boundary of the subzone (Fig 3). Quercus shows a more or less similar trend; while other tree pollen remains relatively unchanged. The cultivated tree Juglans shows a low-value continuous curve. Individual grains of Vitis were also encountered. Pollen of cultivated herbs is mainly represented by Poaceae ( $>40 \mu \mathrm{m})$ and other herbs mainly by Artemisia and Poaceae $(<40 \mu \mathrm{m})$. Cyperus is still the main constituent of the wetland group, however, percentages decrease in the upper part of the subzone. Pediastrum is the main NPP and Desmodesmus shows a small peak in the lower half of the subzone (Fig. 4). The main feature of subzone EYK-Ic (156-132 cm; ca. 300-200 cal yr BP; ca. 1650 to $1750 \mathrm{AD})$ is marked by the decrease of Alnus and a prominent maximum of Cyperus. Poaceae $(<40 \mu \mathrm{m})$, Urtica, and Artemisia show low values. Pediastrum and Desmodesmus are absent in this section of the record (Fig. 4). Macro-charcoal particles increased.

212 Zone EYK-II (132-68 cm, ca. 200-100 cal yr BP; ca. 1750 to 1850 AD) is characterized by very high values 213 (up to 86\%) of tree and shrub pollen, with Alnus being the most important contributor, followed by Carpinus 214 betulus, Fagus, Zelkova/Ulmus, Quercus, Fraxinus, and a small proportion of Salix. Pollen of Pterocarya is generally low throughout the record; however, values slightly increase in this zone. Among the pollen types attributable to cultivated taxa, Poaceae $(>40 \mu \mathrm{m})$ and Vitis are the main constituents in the lower half of the zone and Juglans in the upper. NAP pollen types show negligible values. In the wetland group, Cyperus and other Cyperaceae have higher values at the end of the zone. Fern spores are almost absent. The NPP group is characterized by the dominance of Pediastrum and moderate values of Botrycocuus, Zygnemataceae, and low values of dinocysts. Higher values of macro-charcoal particles occur at the beginning of the zone.

221 Zone EYK-III (68-0 cm, ca. 100-0 cal yr BP; ca. 1850 AD to present) is marked by a low pollen content, a strong decline of Alnus pollen (down to $17 \%$ ), and a notable increase of Poaceae ( $>40 \mu \mathrm{m}$ ), which can be attributed to Oryza sativa. Plantago lanceolata type is highest represented in this zone of the whole record. Herbs increase to the highest proportion, which are mainly represented by Poaceae $(<40 \mu \mathrm{m})$, Chenopodiaceae, Artemisia, Urtica, and Galium. The main constituent of the wetland group is now pollen of other Cyperaceae. Low values of Ludwigia, Sparganium/Typha type, and Typha latifolia type were also seen. Fern spores reach the highest values in the lower half of this zone. Desmodesmus shows two prominent peaks. Other NPPs of the zone include Pediastrum and Zygnemataceae with high abundance. Dinocysts form a continuous curve with relatively high values. Podospora rises in the top samples. Except for a small peak at the start of the zone, macro-charcoal particles are negligible.

232 The XRF analysis provides geochemical elemental compositions in the EYK sediment core in high-resolution.

$233 \mathrm{The} \mathrm{Ca} / \mathrm{Ti}$ and $\mathrm{Ca} / \mathrm{Fe}$ ratio curves (Fig. 5), show low fluctuations between 300 and $68 \mathrm{~cm}$ core depth (pollen zone

234 EYK I and II). Inc/coh shows a general increasing trend. Marked changes in the ratios of inc/coh, $\mathrm{Ca} / \mathrm{Ti}$, and $235 \mathrm{Ca} / \mathrm{Fe}$ are found in the upper $68 \mathrm{~cm}$ core depth (pollen zone EYK III).

\section{LOI results of EYK core}

238 From 300 to $76 \mathrm{~cm}$ core depth, the $\mathrm{LOI}_{950}{ }^{\circ} \mathrm{C}$ record shows very low values (Fig. 5). From 76 to $30 \mathrm{~cm}, \mathrm{LOI}_{950}{ }^{\circ} \mathrm{C}$ 239 shows a continuously increasing trend and then an abrupt increase in the upper $30 \mathrm{~cm}$ of the core. $\mathrm{LOI}_{550}{ }^{\circ} \mathrm{C}$, shows 
240 more fluctuations. From 300 to $210 \mathrm{~cm}$ the $\mathrm{LOI}_{550}{ }^{\circ} \mathrm{C}$ has relatively low values. From 210 to $130 \mathrm{~cm}$ it shows an

241 increasing trend to the highest level throughout the whole record. While from 130 to $74 \mathrm{~cm}$ the $\mathrm{LOI}_{550}{ }^{\circ} \mathrm{C}$ record

242 shows an abrupt sharp decrease and then small fluctuations. From the upper $74 \mathrm{~cm}$ the $\mathrm{LOI}_{550}{ }^{\circ} \mathrm{C}$ record shows a

243 strong increase.

245 Results from the Bibi Heybat alder swamp sediment core

246 Stratigraphy and chronology

247 The stratigraphy of the BBH sediment core is illustrated in Fig. 7. Four markedly different deposits can be visually

248 identified. From 116 to $30 \mathrm{~cm}$, the sediment is dominated by brownish clay; in between it is composed by several

249 sandy layers, from 84 and $57 \mathrm{~cm}, 52$ to $46 \mathrm{~cm}$ and from 41 to $38 \mathrm{~cm}$, respectively. The upper $30 \mathrm{~cm}$ is composed

250 by soft dark organic matter.

251 There are three radiocarbon dates for the BBH core (Table 1). The date from the middle section of the core at 70

$252 \mathrm{~cm}$ is about $5000 \mathrm{cal} \mathrm{yr} \mathrm{BP,} \mathrm{while} \mathrm{the} \mathrm{bottom} \mathrm{date} \mathrm{at} 116 \mathrm{~cm}$ is ca. $1450 \mathrm{cal} \mathrm{yr}$ BP. Considering the marine

253 transgression that occurred during the LIA in the lowland, the old age in the middle part of the core was most

254 likely due to the marine sediment deposition of older material. Therefore, this old age was not considered in the

255 age-depth model (Fig. 2b). Based on this age-depth model, the age of the BBH pollen zones have been calculated.

256 However, these calculated ages have to be seen as a rough estimation of the pollen zones due to the difficulties to

257 date the middle part of the core.

258

259

\section{Pollen analytical results}

260 According to the CONISS cluster analysis, three pollen zones (Zone BBH-I, BBH-II, BBH-III) can be recognized 261 (Fig. 7).

262 Zone BBH-I (116-53 cm; ca. 1450 to 450 cal yr BP; ca. 500 to 1500 AD) is marked by low representation of

263 tree and shrub pollen, which at the beginning of the record show slightly higher amounts of Alnus. Quercus and

264 Pterocarya are represented with low values in the lowermost samples followed by higher values of Pinus

265 thereafter. Salix shows the highest occurrence in this zone. Anthropogenic indicators are mainly represented by

266 relatively frequent cultivated Poaceae $(>40 \mu \mathrm{m})$ and Pantago lanceolata type. Herb pollen is dominant and mostly

267 contributed by Chenopodiaceae, Poaceae $(<40 \mu \mathrm{m})$, Artemisia, and Asteraceae. Wetland pollen is mainly

268 represented by Cyperaceae. Fern spores are less represent at the lower part, while slightly increase to the upper

269 part of the zone. Among the NPPs, Glomus is the most abundant type and has a prominent peak in the lower half

270 of the zone. Dinocysts, foraminifera, and Zygnemataceae start to be continuously present in the upper part of the

271 zone (Fig. 6).

272 Zone BBH II (53-16 cm; ca. 450 to 50 cal yr BP; ca. 1500 to 1900 AD) is characterized by a shift from herb

273 pollen dominance in the lower half of the zone to higher values of Alnus in the upper part of the zone. While other

274 tree and shrub pollen such as Pterocarya, Quercus, and Salix decrease towards the end of the zone. Anthropogenic

275 indicators decrease. Herb pollen values are contributed by Chenopodiaceae, Poaceae $(<40 \mu \mathrm{m})$, Artemisia and

276 Asteraceae which shows a decreasing trend towards the upper part of this zone. Cyperaceae is still the main

277 constituent of the wetland pollen group, in which individual grains of Lemna minor, Potamogeton, and Typha

278 latyfolia type were also encountered. The lower part of the zone is characterized by moderate values of trilete fern

279 spores while the upper part shows substantial values of monolete spores. Several NPPs including Diporotheca, 
280 Sordaria spp., Zygnemataceae, and Glomus show their highest values throughout the record. The dinocysts show

281 an increasing trend in this zone.

282 Zone BBH III (16-0 cm; ca. 50 cal yr BP to present; ca. 1900 AD to present). The tree and shrub pollen group,

283 now mainly composed of Alnus, shows an increasing trend and is mainly by an increase of Alnus, Pterocarya,

284 and slightly Juglans. Anthropogenic indicators such as Poaceae ( $>40 \mu \mathrm{m})$ and Plantago lanceolata type are very

285 rare. Herb pollen of Chenopodiaceae, Poaceae $(<40 \mu \mathrm{m})$, Artemisia, and Asteraceae decrease to the lowest

286 amount. The wetland pollen group with Cyperaceae is represented with the lowest values. Fern spores are almost

287 not registered in this zone. Among the NPPs, Diporotheca decrease towards the upper part. Sordaria spp. and

288 Glomus decline from the highest to lowest values. Zygnemataceae have relatively high values.

289

290 Interpretation and discussion of the EYK record

291 Phase I: ca. 1150 to 1750 AD (ca. 800-200 cal yr BP, Zone EYK-I)

292 For this period the pollen record indicate that the studied coastal plain of the southern CS further inland was

293 dominated by alder forest and at higher elevated areas forests mixed temperate deciduous trees such as Pterocarya,

294 Carpinus betulus, Fagus, Zelkova/Ulmus, Buxus, and Quercus. Ferns were not so frequent in the study area.

295 Cultivated plants like Juglans, Vitis and Oryza, indicate human activities in the coastal plains. Human disturbances

296 in the landscape is indicated by the occurrence of Plantago lanceolata. Small areas of open grassland occurred,

297 documented by some Poaceae $(<40 \mu \mathrm{m})$, Urtica and Artemisia. Large areas of wetlands were found already at that

298 time, rich in Cyperus and with lower frequency of other Cyperaceae species. Shallow open water bodies are

299 indicated by Myriophyllum. The development of wetlands in the study area is most likely due to the freshwater

300 discharge of rivers, suggested by the high abundance of the freshwater algae Pediastrum.

301 LOI provides a reliable record for carbonate and organic content in the sediments of the EYK core. The low

$302 \mathrm{LOI}_{950^{\circ} \mathrm{C}}$ values in this period suggest a low carbonate content in the sediment. Carbonate dissolution can occur in

303 low water levels (Almendinger and Leete 1998), suggesting a low water level in the alder forest of the study area.

304 A general low carbonate is also indicated by the low values of $\mathrm{Ca} / \mathrm{Ti}$ and $\mathrm{Ca} / \mathrm{Fe}$ ratios of the $\mathrm{XRF}$ data. $\mathrm{The}_{\mathrm{LOI}} \mathrm{I}_{50}$

$305{ }^{\circ} \mathrm{C}$ record indicates a low organic content in the sediments with an increasing trend, which is supported by the

306 increase of inc/coh record (Fig. 5). The increase of the organic content can be related to the increasing plant

307 productivity (Bauer and Black, 1994).

308 More specific from ca. 1150 to 1350 AD (ca. 800-600 cal yr BP, subzone EYK-Ia), the dominance of the wet

309 alder forest and the high proportion of temperate mixed deciduous forest suggest optimal climatic conditions in

310 northern Iran during this recorded period, which belongs to the second part of the MEWP. During the MEWP

311 (between ca. 980 and 1210 AD), the CS level was low (Beni et al. 2013). The CS level is mainly influenced by

312 the hydrological balance between the influx of water input (river discharge and precipitation) and output through

313 evaporation over the CS and the watershed (Kroonenberg et al. 2000; Arpe et al. 2012). Studies suggest that the

314 global temperature during the MEWP (900 to 1300 AD) was at least similar to the present-day (Easterbrook, 2016)

315 and even $1{ }^{\circ} \mathrm{C}$ warmer in the Northern Hemisphere as recorded by the Greenland ice core (GISP2), (Stuiver and

316 Grootes 2000). Such general higher temperatures likely caused higher evaporation in CS, which led to the lower

317 CS level during the MEWP.

318 The green algae Pediastrum is frequent in freshwater bodies, such as shallow and eutrophic lakes (Jankovská and

319 Komárek 2000). Abundant Pediastrum in the Eynak lagoon, suggest higher rainfall probably due to relatively wet 
320 climatic conditions in the study area. As cultivated trees of Juglans as well as Oryza cultivation (Poaceae $>40 \mu \mathrm{m})$ were relatively frequent, it is suggested that cultivation activities were relatively high during this period, maybe due to a warmer condition of the MEWP. The highest occurrence of fire at the beginning of the record might be 323 due to human activities.

324 From ca. 1350 to 1650 AD (ca. 600-300 cal yr BP, subzone EYK-Ib), the further expansion of the alder forest occurred during the early LIA, suggesting that the lowland of northern Iran was even wetter than in the previous period. This led to a retreat of the mixed forest in the higher elevated areas. Human activities, especially rice cultivation, were less frequent. Cyperus is still the dominant taxa around and in the shallow lagoon. The presence of green algae Pediastrum and Desmodesmus, suggest that the lagoon was dominated by freshwater. During this period, the CS level was still low. Beni et al. (2013) suggest that during early LIA, the CS water level dropped and reached a low stand at ca. $1600 \mathrm{AD}$. Afterward, the CS water level started to increase again. The less frequent fires in this period might be related to wetter and cooler conditions with less human activities.

332 From ca. 1650 to 1750 AD (ca. 300-200 cal yr BP, subzone EYK-Ic), the pollen record suggests that the forests, both in the lower and higher elevated areas, declined for a short period accompanied by a slight decrease in grassland and anthropogenic indicators. In the wetlands Cyperus was frequent. Pediastrum decrease to the lowest values, which suggests that during this period, the climate became drier. The palaeo-temperature reconstruction during the main LIA phase (ca. 1680 to 1800 AD) in the central Eastern Alps suggests that the temperature reached the lowest values (Ilyashuk et al. 2019). The relatively cold and dry climate can be the major factor causing the decline of forests. Fires became more frequent again, probably related to drier conditions and/or human activities. This can be related to the decrease of CS level from ca. $23 \mathrm{~m}$ b.s.l. to $26 \mathrm{~m}$ b.s.l. during this period (Beni et al. 340 2013).

\section{Phase II: ca. 1750 to 1850 AD (ca. 200-100 cal yr BP, Zone EYK-II)}

342 During this period, the pollen record indicates the largest expansion of the wet alder forest, while the mixed 343 deciduous forest at elevated areas increased again at the end of this period. This is likely related to a wetter climate as the CS level was relativity high during this period (Beni et al. 2013). The proportions of cultivated plants reduced slightly and became unstable. The grassland which is dominated by Poaceae, Chenopodiaceae, Urtica, and Artemisia, retreated to their smallest areas. Compared to the previous Phase I, the wetland taxa markedly decreased, probably due to the expansion of the forest with a decrease at the end of the period.

348 The still low carbonate content, indicated by the low values of $\mathrm{LOI}_{950}{ }^{\circ} \mathrm{C}$ as well as low values of $\mathrm{Ca} / \mathrm{Fe}$ and $\mathrm{Ca} / \mathrm{Ti}$ ratios (Fig. 5), suggest that the water level of the alder forest was still low. The inc/coh ratio indicates that the organic matter input to the wetlands increased during this period. However, the declined values of $\mathrm{LOI}_{550^{\circ} \mathrm{C}} \mathrm{record}$ indicate a low organic content and suggesting low organic productivity. This might be related to the generally low temperature and unstable climate conditions druing the coldest main LIA phase.

\section{Phase III: ca. 1850 AD to present (ca. 100 cal yr BP to present, Zone EYK-III)}

354 In the last ca. 170 years, the pollen record indicates the strongest change in the vegetation. The coastal alder forest showed the strongest decline throughout the whole record. Also Pterocarya became rare in the forest. The grassland area, frequent in Poaceae, Chenopodiaceae, Artemisia, Urtica, and Galium, increased markedly. Rice cultivation also markedly expanded during this period. Also, the increase of the Plantago lanceolata suggests that strong human disturbance occurred. These changes indicate that large areas of the alder forest have been replaced by human activities. Nowadays, in the lowland of the study area alder forests are almost entirely converted to 
360 urban and agricultural land. Changes in the wetland vegetation were indicated by the more frequent occurrence

361 of Cyperaceae, Ludwigia, Sparganium and Typha, while Cyperus was absent. The reduction can be related as well

362 to the marked increase in human activities.

363 The LOI and XRF data also indicate marked changes in the environment for the last about 170 years. The abrupt

364 increase in the $\mathrm{LOI}_{950}{ }^{\circ} \mathrm{C}$ record reflects a strong increase in carbonate content of the sediments, which is also

365 reflected by the high ratios of $\mathrm{Ca} / \mathrm{Fe}$ and $\mathrm{Ca} / \mathrm{Ti}$. The high carbonate content was likely due to the increase of water

366 level in the wetlands, which also mark the formation of the EYK lagoon. The stable high values of $\mathrm{Ca} / \mathrm{Fe}, \mathrm{Ca} / \mathrm{Ti}$,

367 and $\mathrm{LOI}_{950}{ }^{\circ} \mathrm{C}$ record suggests that the modern Eynak lagoon was established about 50 years ago. The hydrological

368 changes in the Eynak lagoon were very likely due to human activities.

369 Abrupt strong changes in the geochemical composition of the wetland deposits have been also detected in the

370 ZBR record for the same period ( $\mathrm{Gu}$ et al. 2021). The increased water level of the lagoon can be related to the

371 dam reconstruction in the study area. A previous study also documents that dams and dikes were frequently

372 constructed around the wetlands in northern Iran for water storage, maintenance of irrigation systems to increase

373 rice production and to improve the cultivation (Kardavani 1991). The very rare occurrence of fires might be related

374 to the decrease of burning activities, increasing of the water table as well as the wet condition surrounding the

375 lagoon. Meanwhile, the increased $\mathrm{LOI}_{950}{ }^{\circ} \mathrm{C}$ record suggests that the continuous increase of organic content

376 deposits which also suggests the improvement of organic productivity can be related to human activities.

377

\section{Interpretation and discussion of the BBH core}

379 Phase I: ca. 500 to 1500 AD (ca. 1450 to 450 cal yr BP; Zone BBH-I)

380 The BBH pollen record suggests that in the lower elevated coastal areas close to the CS of northern Iran, the

381 landscape was dominated by open grassland vegetation with Chenopodiaceae, Poaceae, Artemisia, and

382 Asteraceae. Alder forest occurred only in small areas at the beginning of the record and declined during this

383 period. Later, since around $1050 \mathrm{AD}$, the alder forest started to re-expand slightly. Anthropogenic indicators such

384 as Poaceae $(>40 \mu \mathrm{m})$ and Plantago lanceolata type are relatively frequent, indicating rice cultivation and other

385 human disturbances in the study area. Wetlands, mainly shown by the Cyperaceae, were also first relatively small

386 and increased in the second half of the period. Also from 1050 AD onwards, marine dinocysts and foraminifera

387 were found in the deposits, indicating that the coring area of BBH was under the influence of brackish water from

388 the CS, maybe via the Sefied Rud River (Fig. 1). This is further confirmed by the presence of sandy layers in the

389 sediment core (84 to $57 \mathrm{~cm}$ depth). Glomus is a good indicator of active soil erosion, referring to limited soil

390 moisture (Medeanic and Silva 2010; van Geel 2002). During this period, the high abundance of Glomus, which

391 indicates low soil moisture hence active soil erosion under relatively dry conditions with heavy rainfalls.

392 Phase II: ca. 1500 to 1900 AD (ca. 450 to 50 cal yr BP; Zone BBH-II)

393 This is a transitional period, the dominant open grassland changed to an alder swamp forest with relatively

394 frequent occurrence of Pterocarya. Ferns increased markedly in the second part of this period and might have 395 played a role in the successional development of the alder swamp. The decrease of Poaceae pollen $(>40 \mu \mathrm{m})$

396 suggests that the rice cultivation reduced slightly in the study area. Wetland plants increased slightly and were

397 dominated by Cyperaceae. The higher occurrence of dinocysts and foraminifera suggests that during this period,

398 the BBH coring site was still influenced by the brackish water of the CS. Soil erosion still occurred, as suggested

399 by the continuous high presence of Glomus. In the second part of this period (ca.1800 to 1900 AD), the abundance 
of Sordaria spp. and Diporotheca is high. Diporotheca can either indicate soil disturbance and extensive soil erosion or suggest a wet and eutrophic habitat (Hillbrand et al. 2012) while Sordaria spp. is a good indicator for the large herbivores' animals (Baker et al. 2016). Therefore, the high abundance of Sordaria spp. and Diporotheca, suggest that the wetland was disturbed by anthropogenic activities, which was likely due to grazing activities. The highest dominance of Alnus indicates that the largest expansion of alder forest occurred only during this relatively recent period. In this phase, the abundant Zygnemataceae which is commonly associated with shallow water habitats (Worobiec 2014), accompanied by the dominance of Alnus, probably refers to the final formation of the wet alder swamp. At the study site, the area of open vegetation retreated markedly as well as the cultivated area. The decreasing trend of Sordaria spp., Diporotheca, and Glomus from the highest values to the lowest in the upper record, suggest less anthropogenic disturbance (cattle grazing) in the area. The open wetland areas became very small as indicated by the decrease of Cyperaceae.

412

\section{Comparison between the two new sites and other sites in the lowlands of northern Iran}

414 This study indicates a marked difference in the vegetation composition in the lowland of the EYK study area 415 further inland and the BBH area near the coast of the CS (Fig. 1). The BBH record (15 m b.s.l.) shows that the 416 studied coastal area was mainly dominated by open grassland vegetation from 500 to $1850 \mathrm{AD}$. The wet alder 417 forest area was the lowest between 750 and $1050 \mathrm{AD}$. The EIG record at ca. $550 \mathrm{~m}$ elevation from the northern 418 slope of the central Alborz Mountains also indicates little presence of alder forest before $1050 \mathrm{AD}$ (Ramezani et 419 al. 2008). Stronger soil erosion was recorded in the BBH core, which can be related to the strong erosive environmental condition during MEWP (900 to 1300 AD). Such MEWP related soil erosion is also recorded by the EIG record (Ramezani et al. 2008). The BBH pollen record shows that a slight increase of alder forest occurred after $1050 \mathrm{AD}$ and between 1450 and $1650 \mathrm{AD}$, while a stronger expansion occurred from 1850 to $1950 \mathrm{AD}$. The largest expansion that occurred was recently after $1950 \mathrm{AD}$.

424 The EYK site (5 $\mathrm{m}$ a.s.1.), located further inland and $20 \mathrm{~m}$ higher than the BBH coring site, showed an increasing trend of alder forest expansion between 1150 and $1850 \mathrm{AD}$, except the strong decline between 1650 to $1750 \mathrm{AD}$. This stronger reduction is also shown in the pollen record of the BBH core. After the LIA at $1850 \mathrm{AD}$, with the increase of open vegetation and cultivated areas, the alder forest declined strongly at the EKY site. The study by Beni et al. (2013) indicates that during the MEWP, the water level of the CS was relatively low (ranging from ca. $23.5 \mathrm{~m}$ to $25.5 \mathrm{~m}$ b.s.l.), while during the second part of the LIA, the level of the CS was as high as ca. $21 \mathrm{~m}$ b.s.l. (compared with $27 \mathrm{~m}$ b.s.l. in 2014). Between MEWP and LIA (1250 and 1350 AD) the CS level reached as high as $19 \mathrm{~m}$ b.s.l. Therefore, it is supposed that large lowland regions were influenced by the invasion of brackish water from the CS during the high water level stands of the CS level between MEWP and LIA and in the second part of the LIA.

434 However, the frequent presence of dinocysts and foraminifera in the BBH record (15 m b.s.l.), suggests that the BBH site was already influenced by brackish water since $1050 \mathrm{AD}$. Due to the location of the EYK core further inland at a higher elevation, the ecosystem was not directly under the brackish water influence from the CS, but with the Sefid Rud River connection is possible. However, the increasing trend of alder forest and other broadleaved forest expansion in the EYK study area, suggest that the moisture increase can be linked to the increased CS level. 
440 The record from the coastal lagoon Amirkola (Fig. 1), located at $23 \mathrm{~m}$ b.s.l., indicates that the vegetation was

441 dominated by dense alder forest since the beginning of the record at ca. $1620 \mathrm{AD}$, and then the lagoon was

442 continuously influenced by the CS until ca. 1800 AD (Leroy et al. 2011). Unfortunately, due to the younger age

443 of the Amirkola record, the CS influence of the coastal area could not be reconstructed. However, the BBH core

444 suggests that the CS water influence in the lowland of the BBH area occurred at least since 1050 AD as indicated

445 by the continuous occurrence of dinocysts and foraminifera in the record.

446 After the LIA at AD 1850, as the CS rapidly regressed, the BBH core showed that the alder forest developed in 447 the coastal region and continued to expand in the study area. While in the slightly elevated area further inland,

448 where human activities were pronounced, the EYK record shows a marked reduction of alder forest and an 449 increase of grassland and cultivated plants. Haghani et al. (2016) indicated that after the brackish water incursion 450 during LIA, the environment was unsuitable for agriculture. Moreover, the abundance of water algae 451 Zygnemataceae from the $\mathrm{BBH}$ record suggests that the ecosystem changed to alder swamp ecosystem with 452 shallow water. Therefore, due to the increase of water tables and the formation of the swamp ecosystem, the BBH 453 area was probably not favored for agriculture and grazing. The BBH area was then abandoned as humans, which 454 is likely moved to more favorable areas. This might explain less human activities and disturbance in the BBH 455 record during the last 100 years. The development of dense alder forests in the BBH area was likely related to less 456 anthropogenic activities. However, as the EYK record shows a strong reduction of the alder forest, deforestation 457 became intense during the last 170 years. The increase of the anthropogenic impact has been also recorded in ZBR 458 wetlands during the last 100 years (Gu et al. 2020).

459

\section{Summary and Conclusion}

461 The two new multi-proxy records, including pollen, spores, NPPs, charcoal, LOI and geochemical elements, from 462 the coastal plain of northern Iran, provide new insights into vegetation and environmental changes during the late 463 Holocene. The results of the archives from the coastal Bibi Heybat (BBH) alder swamp and the Eynak (EYK) 464 lagoon further inland indicate that since the beginning of recorded time (BBH since 500 AD, EYK since 1150 $465 \mathrm{AD})$ the areas of alder forest were smaller in particular at BBH. Here only smaller areas were covered by alder 466 forest. For the recorded MEWP (900 to 1300 AD) with relatively small areas of alder swamp, it is suggesting that 467 the climate was warmer and drier. The dry condition is especially indicated by the soil erosion in the BBH record 468 and the high fire frequency of the EYK macro-charcoal record. During the cold phase in the LIA period with the 469 CS high stands between 1600 and $1850 \mathrm{AD}$, both records indicate an expansion of alder forest, which might be 470 related to humid air mass from the CS that could potentially contribute to the forest expansion. The inland EYK 471 record indicates that since the last 170 years, a strong reduction in alder forest occurred, while the coastal BBH 472 record shows the opposite for the last about 100 years. This indicates little anthropogenic impact in the coastal 473 area of the BBH alder swamp, but intensified human impact in the Eynak wetland area, might be related to changes 474 of the coastal environment, and with the influence of the brackish water of CS, the BBH alder swamp was not so 475 suitable for agriculture anymore. These new records show that relatively large and little disturbed open wetlands 476 occurred in the EYK study area which changed by the strong human impacts over the last 170 years, while in the 477 BBH study area, open wetlands were mostly replaced by the alder forest extension since the last about 100 years. 478 These two new environmental records suggest that late Holocene climatic fluctuations, changes in CS level, but 
in particular the intensity of human activities are the most important factors controlling the dynamics of the northern Iranian coastal vegetation and wetlands.

\section{Acknowledgments}

483 We would like to acknowledge the German Science Foundation (DFG) for financial support (BE2116/31-1) for this project. We thank in particular Leila Homami Totmaj and Iranian colleagues for coring of the EYK sediment core. We thank Katherina Tesar for the help with lab work and Kartika Anggi Hapsari for critical reading of the manuscript.

\section{Declarations}

489 Funding (This research is financial supported by the German Science Foundation (DFG) for Prof. Dr. Hermann

490 Behling, and with the support the first author did the postdoc research)

491 Conflicts of interest/Competing interests (not applicable)

492 Ethics approval (not applicable)

493 Consent to participate (not applicable)

494 Consent for publication (not applicable)

495 Availability of data and material (The datasets used and/or analysed during the current study are available from 496 the corresponding author on request.)

497 Code availability (not applicable)

Authors' contributions (All of the co-authors contributed to the study conception and design. Data analysis and the draft of the manuscript were performed by Dr. Fang Gu. Dr. Kamaleddin Alizadeh and Prof. Dr. Hermann Behling commented on the manuscript. All authors read and approved the final manuscript)

\section{References}

Almendinger JE, Leete JH (1998). Peat characteristics and groundwater geochemistry of calcareous fens in the Minnesota River Basin, USA. Biogeochemistry 43(1):17-41.

Arpe K, Leroy SAG, Lahijani H, Khan V (2012). Impact of the European Russia drought in 2010 on the Caspian Sea level. Hydrology and Earth System Science 16: 19-27.

Arpe K, Leroy SA (2007). The Caspian Sea Level forced by the atmospheric circulation, as observed and modelled. Quaternary International 173: 144-152.

Bahmaniar MA, Ranjbar GA, Ahamafian SH (2007). Effects of N and K applications on agronomic characteristics of two Iranian and landrace rice (Oryza sativa L.) cultivars. Journal of Biological Science 10(6): 880-886.

Baker AG, Cornelissen P, Bhagwat SA, Vera FW, Willis KJ (2016). Quantification of population sizes of large herbivores and their long-term functional role in ecosystems using dung fungal spores. Methods in Ecology and Evolution 7(11): 1273-1281.

Barbier EB, Hacker SD, Kennedy C, Koch EW, Stier AC, Silliman BR (2011). The value of estuarine and coastal ecosystem services. Ecological Monographs 81: 169-193.

Battarbee RW, Berglund BE (1986). Handbook of Holocene palaeoecology and palaeohydrology. Diatom analysis. In: Berglund, BE (Ed.), John Wiley \& Sons Ltd., Chichester, 527-570.

Bauer A, Black A L (1994). Quantification of the effect of soil organic matter content on soil productivity. Soil Science Society of America Journal 58(1): 185-193.

Beni AN, Lahijani H, Harami RM, Arpe K, Leroy SAG, Marriner N, Berberian M, Andrieu-Ponel V, Djamali M, Mahboubi A, Reimer PJ (2013). Caspian Sea level changes during the last millennium: historical and geological evidences from the south Caspian Sea. Climate of the Past 9: 1645-1665.

Bertini A(2003). Early to Middle Pleistocene changes of the Italian flora and vegetation in the light of a chronostratigraphic framework. Il Quaternario 16(1): 19-36.

Beug HJ (2004). Leitfaden der Pollenbestimmung für Mitteleuropa und angrenzende Gebiete. Verlag Dr Friedrich Pfeil. 
Biglari F, Jahani V (2011). The Pleistocene Human Settlement in Gilan, Southwest Caspian Sea: Recent Research. Eurasian Prehistory 8 (1-2): 3-28.

Crowley T J, Lowery TS (2000). How warm was the medieval warm period?. AMBIO: A Journal of the Human Environment 29(1): 51-54.

Croudace IW, Rindby A, Rothwell RG (2006). ITRAX: description and evaluation of a new multi-function X-ray core scanner. In: Rothwell, R.G. (ed.), New Techniques in Sediment Core Analysis. Geological Society, London, Special Publications 267(1): 51-63.

Davies S, Lamb H, Roberts S (2015) Micro-XRF Core Scanning in Palaeolimnology: Recent Developments. In: Croudace I., Rothwell R. (eds) Micro-XRF Studies of Sediment Cores. Developments in Paleoenvironmental Research, Vol 17. Springer, Dordrecht.

Dean WE (1974). Determination of carbonate and organic matter in calcareous sediments and sedimentary rocks by loss on ignition; comparison with other methods. Journal of Sedimentary Research 44(1): 242-248.

Djamali M, Beaulieu JLde, Campagne P, Andrieu-Ponel V, Ponel P, Leroy SAG, Akhani H (2009). Modern pollen rain-vegetation relationships along a forest-steppe transect in the Golestan National Park, NE Iran. Review of Palaeobotany and Palynology 153 (3-4): 272-281.

Easterbrook DJ (2016). Using patterns of recurring climate cycles to predict future climate changes. In: Easterbrook DJ (Ed.) Evidence-Based Climate Science, Second Edition, Oxford, UK, Elsevier, 395-411.

Faegri K, Iversen J (1989). Textbook of pollen analysis. $4^{\text {th }}$ (ed.) John Wiley, 328 pp.

Gedan KB, Silliman BR, Bertness MD (2009). Centuries of human-driven change in salt marsh ecosystems. The Annual Review of Marine Science 1: 119-141.

Gu F, Ramezani E, Alizadeh K, Behling H (2021). Vegetation Dynamics, Environmental Changes and Anthropogenic Impacts on the Coastal Hyrcanian Forests in Northern Iran. Journal of Coastal Research (in print).

Grimm EC (1987). CONISS: A Fortran 77 program for stratigraphically constrained cluster analysis by the method of the incremental sum of squares. Computer Geoscience 13: 13-35.

Haghani S, Leroy SA, Khdir S, Kabiri K, Naderi Beni A, Lahijani HAK(2016). An early 'Little Ice Age’ brackish water invasion along the south coast of the Caspian Sea (sediment of Langarud wetland) and its wider impacts on environment and people. The Holocene 26(1): 3-16.

Halpern BS, Walbridge S, Selkoe KA, Kappel CV, Micheli F, D'Agrosa C, Bruno JF, Casey K S, Ebert C, Fox HE, Fujita R (2008). A global map of human impact on marine ecosystems. Science 319: 948-952.

Heiri O, Lotter AF, Lemcke G (2001). Loss on ignition as a method for estimating organic and carbonate content in sediments: reproducibility and comparability of results. Journal of Paleolimnology 25(1): 101-110.

Heydarizad M, Raeisi E, Sorí R, Gimeno L (2019). Developing Meteoric Water Lines for Iran Based on Air Masses and Moisture Sources. Water 11(11): 2359, https://doi.org/10.3390/w11112359.

Higuera PE, Brubaker LB, Anderson PM, Hu FS, Brown TA (2009). Vegetation mediated the impacts of postglacial climatic change on fire regimes in the south-central Brooks Range, Alaska. Ecological Monographs 79: 201-219.

Higuera PE, Whitlock C, Gage JA (2011). Linking tree-ring and sediment-charcoal records to reconstruct fire occurrence and area burned in subalpine forests of Yellowstone National Park, USA. The Holocene 21(2): 327-341.

Hillbrand M, Hadorn P, Cugny C, Hasenfratz A, Galop D, Haas JN (2012). The palaeoecological value of Diporotheca rhizophila ascospores (Diporothecaceae, Ascomycota) found in Holocene sediments from Lake Nussbaumersee, Switzerland. Review of Palaeobotany and Palynology 186: 62-68.

Hoogendoorn RM, Boels JF, Kroonenberg SB (2005). Development of the Kura delta, Azerbaijan; a record of Holocene Caspian Sea-level changes. Marine Geology 222: 359-380.

Ilyashuk EA, Heiri O, Ilyashuk BP, Koinig KA, Psenner R (2019). The Little Ice Age signature in a 700-year high-resolution chironomid record of summer temperatures in the Central Eastern Alps. Climate dynamics 52(11): 6953-6967.

Jankovská V, Komárek J (2000). Indicative value of Pediastrum and other coccal green algae in palaeoecology. Folia Geobotanica 35(1): 59-82.

Jeihouni M, Kakroodi AA, Hamzeh S (2019). Monitoring shallow coastal environment using Landsat/altimetry data under rapid sea-level change. Estuarine, Coastal and Shelf Science 224: 260-271.

Krasnozhon GF, Lahijani H, Voropayev GV (1999). Evolution of the delta of the Sefidrud River, Iranian Caspian Sea coast, from space imagery. Mapping sciences and Remote Sensing 36(4): 256-264.

Kroonenberg SB, Badyukova EN, Storms JEA, Ignatov EI, Kasimov N S (2000). A full sea-level cycle in 65 years: barrier dynamics along Caspian shores. Sedimentary Geology 134(3-4): 257-274.

Köppen W (1936). Das Geographisches System der Klimate. In: Koppen W, Geiger R (eds.) Handbuch der Klimatologie. Berlin, Gerbruder Borntraeger 1: 1-44.

Kazancı N, Gulbabazadeh T, Leroy SA, Ileri Ö (2004). Sedimentary and environmental characteristics of the Gilan-Mazenderan plain, northern Iran: influence of long-and short-term Caspian water level fluctuations 
on geomorphology. Journal of Marine Systems 46(1-4): 145-168.

Krasnozhon GF, Lahijani H, Voropayev GV(1999). Evolution of the delta of the Sefidrud River, Iranian Caspian Sea coast, from space imagery. Mapping sciences and Remote Sensing 36(4): 256-264.

Köppen W (1936). Das Geographisches System der Klimate. In: Koppen, W. and Geiger, R., (eds.) Handbuch der Klimatologie. Berlin: Gerbruder Borntraeger 1: 1-44.

Leroy SAG, Kakroodi AA, Kroonenberg S, Lahijani HK, Alimohammadian H, Nigarov A (2013). Holocene vegetation history and sea level changes in the SE corner of the Caspian Sea: relevance to SW Asia climate. Quaternary Science Reviews 70: 28-47.

Leroy SAG, Lahijani HAK, Djamali M, Naqinezhad A, Moghadam MV, Arpe K, Shah-Hosseini M, Hosseindoust M, Miller CS, Tavakoli V, Habibi P, Naderi M (2011). Late Little Ice Age palaeoenvironmental records from the Anzali and Amirkola Lagoons (south Caspian Sea): Vegetation and sea level changes. Palaeogeography, Palaeoclimatology, Palaeoecology 302(3-4): 415-434.

Lindshield SM (2016). Protecting nonhuman primates in peri-urban environments: A case study of Neotropical monkeys, corridor ecology, and coastal economy in the Caribe Sur of Costa Rica. In: Cham S, Ethnoprimatology. Springer, 351-369.

Liu L, Lee GA, Jiang L, Zhang J (2007). Evidence for the early beginning (c. 9000 cal. BP) of rice domestication in China: a response. The Holocene 17(8): 1059-1068.

Lotze HK, Lenihan HS, Bourque BJ, Bradbury RH, Cooke RG, Kay MC, Kidwell SM, Kirby MX, Peterson CH, Jackson JBC (2006). Depletion, degradation, and recovery potential of estuaries and coastal seas. Science 312: 1806-1809.

Mann ME, Zhang Z, Rutherford S (2009). Global signatures and dynamical origins of the Little Ice Age and Medieval Climate Anomaly. Science 326: 1256-1260.

Medeanic S, Silva MB (2010). Indicative value of non-pollen palynomorphs (NPPs) and palynofacies for palaeoreconstructions: Holocene Peat, Brazil. International Journal of Coal Geology 84(3-4): 248-257.

Nasrollahzadeh A (2010). Caspian Sea and its ecological challenges. Caspian Journal of Environmental Sciences 8(1): 97-104.

Perșoiu A, Ionita M, Weiss H (2019). Atmospheric blocking induced by the strengthened Siberian High led to drying in west Asia during the $4.2 \mathrm{ka}$, BP event - a hypothesis. Climate of the Past 15(2): 781-793.

Qiu Z, Jiang H, Ding J, Hu Y, Shang X (2014). Pollen and phytolith evidence for rice cultivation and vegetation change during the Mid-Late Holocene at the Jiangli site, Suzhou, East China. PloS ONE: 9(1), e86816, doi: 10.1371/journal.pone.0086816.

Ramezani E, Mohadjer MRM, Knapp HD, Theuerkauf M, Manthey M, Joosten H (2013). Pollen-vegetation relationships in the central Caspian (Hyrcanian) forests of northern Iran. Review of Palaeobotany and Palynology 189: 38-49.

Ramezani E, Mrotzek A, Mohadjer MRM, Kakroodi AA, Kroonenberg SB, Joosten H (2016). Between the mountains and the sea: Late Holocene Caspian Sea level fluctuations and vegetation history of the lowland forests of northern Iran. Quaternary International 408: 52-64.

RStudio Team, 2015. RStudio: Integrated Development for R. RStudio, Inc., Boston, MA. URL http://www.rstudio.com/.

Ravanbakhsh M, Bazdid Vahdati F, Moradi A, Amini T (2013). Flora, life form and chorotypes of coastal sand dune of southwest of Caspian Sea, Gilan province, N. Iran. Journal of Novel Applied Sciences 2(12): 666677.

Shariatpanahi M, Zali F, Tarnas S (2013). Surveying biological situation of Anzali pond and it's custody management strategies along with ecotourism area. Journal of Tourism and Hospitality Research 2(3): 7387.

Stevenson J, Haberle S (2005). Palaeoworks Technical Papers 5. Macro Charcoal Analysis: A modified technique used by the Department of Archaeology and Natural History. Department of Archaeology \& Natural History, Research School of Pacific \& Asian Studies, Australian National University, 8pp.

Stewart AV(1996). Plantain (Plantago lanceolata)-a potential pasture species. In Proceedings of the ConferenceNew Zealand Grassland Association: 77-86.

Stuiver M, Grootes PM (2000). GISP2 oxygen isotope ratios. Quaternary Research 53(3): 277-284.

Talebi K S, Sajedi T, Pourhashemi M (2014). Forests of Iran. In A Treasure From the Past, a Hope for the Future (Vol. 10). Springer.

Tang LY, Mao LM, Shu JW, Li CH, Shen CM, Zhou ZZ (2016). An illustrated handbook of Quaternary pollen and spores in China. Beijing: China Scientific Book Services.

van Geel B (2002). Non-pollen palynomorphs. In: Smol, J.P., Birks, H.J.B., Last, W.M. (eds.) Tracking environmental change using lake sediments. V. 3: Terrestrial, algal and silicaceous indicators. Kluwer, Dordrecht, Springer: 99-119.

Worobiec E (2014). Fossil zygospores of Zygnemataceae and other microremains of freshwater algae from two Miocene palaeosinkholes in the Opole region, SW Poland. Acta Palaeobotanica 54(1): 113-157. 
Worm B, Barbier EB, Beaumont N, Duffy JE, Folke C, Halpern BS, Jackson JBC, Lotze HK, Micheli F, Palumbi SR, Sala E, Selkoe KA, Stachowicz JJ, Watson R (2006). Impacts of biodiversity loss on ocean ecosystem services. Science 314: 787-790.

\section{Figure and Table captions}

653 Figure 1. Map showing the location of sediment cores (red triangles) from the Eynak (EYK) lagoon in Rasht and

654 the Bibi Heybat (BBH) alder swamp.

Figure 3. Pollen percentage diagram, showing the most frequent taxa of the EYK core, grouped into trees/shrubs, anthropogenic indicators, herbs, wetlands, and the pollen zones.

Figure 4. Summary diagram showing the stratigraphy of the sediment core, vegetation groups, ferns, NPPs, pollen sum, concentration and influx, pollen zones, the CONISS dendrogram and pollen zones of the EYK core.

Figure 5. Diagram showing the $\mathrm{LOI}_{550}{ }^{\circ} \mathrm{C}, \mathrm{LOI}_{950}{ }^{\circ} \mathrm{C}$, ratios of $\mathrm{Inc} / \mathrm{coh}, \mathrm{Ca} / \mathrm{Ti}, \mathrm{Ca} / \mathrm{Fe}$ of the $\mathrm{XRF}$ data and macrocharcoal particles of the EYK core.

Figure 6 Pollen, spore, and NPP percentage diagram, showing the most frequent taxa of the BBH core, grouped into trees/shrubs, anthropogenic indicators, herbs, wetlands, as well as ferns and the pollen zones.

671

Figure 7. Summary diagram showing the stratigraphy of the sediment core, vegetation groups, pollen count, concentration and influx, the CONISS dendrogram and pollen zones of the BBH core.

675

Table 1. Radiocarbon dates from sediment core EYK and BBH with the calibrated ages reported for $2 \sigma$ range and with highest probabilities shown in parentheses. 


\section{Figures}

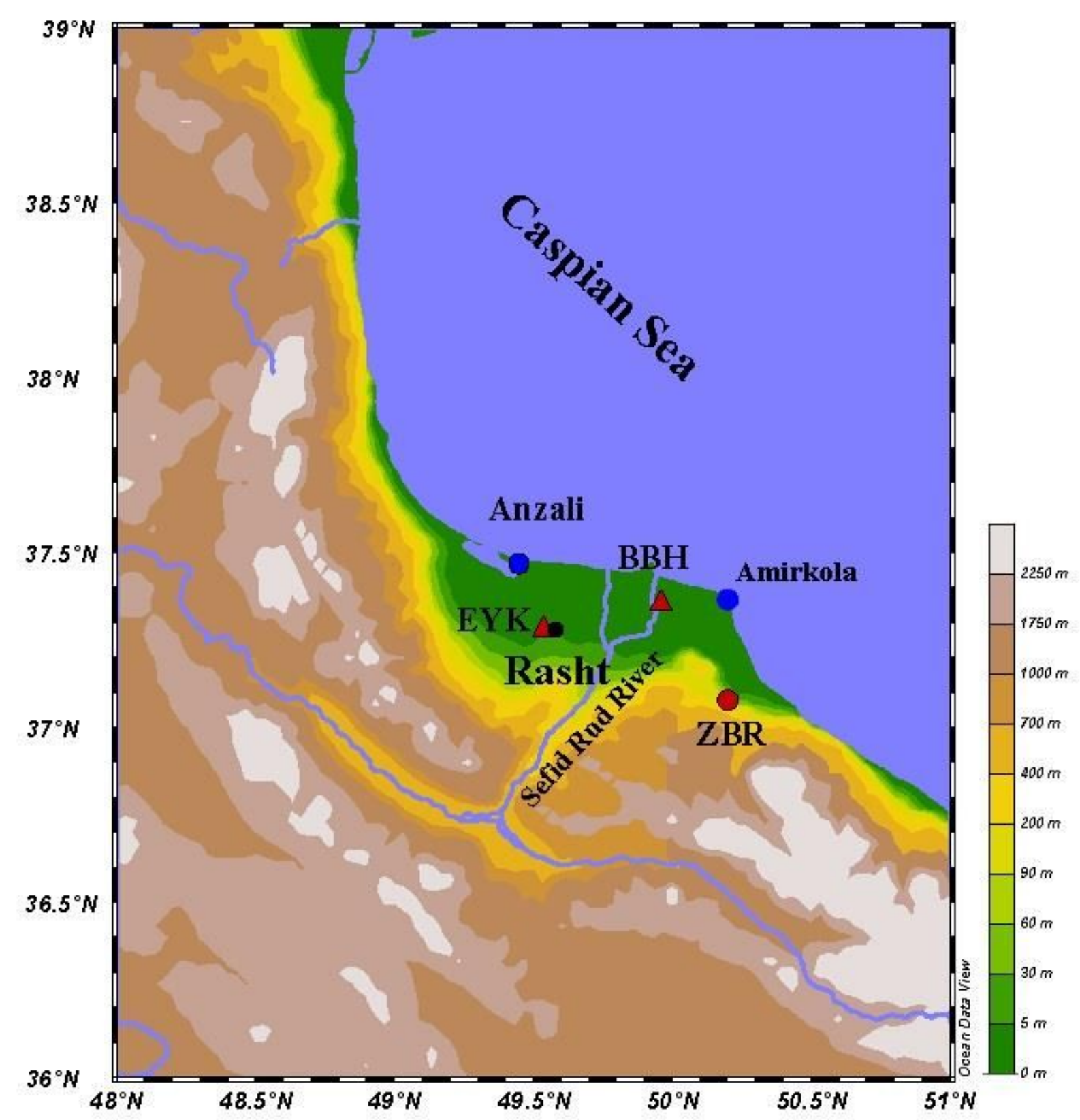

Figure 1

Map showing the location of sediment cores (red triangles) from the Eynak (EYK) lagoon in Rasht and the Bibi Heybat (BBH) alder swamp. Note: The designations employed and the presentation of the material on this map do not imply the expression of any opinion whatsoever on the part of Research Square 
concerning the legal status of any country, territory, city or area or of its authorities, or concerning the delimitation of its frontiers or boundaries. This map has been provided by the authors.

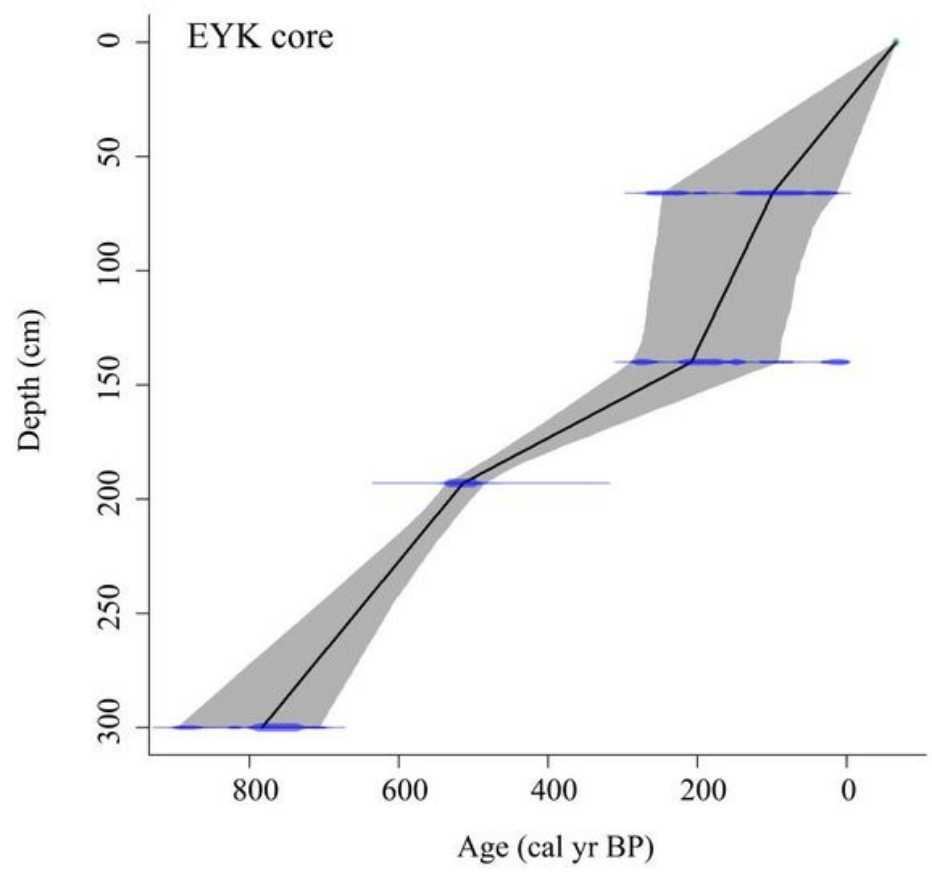

(a)

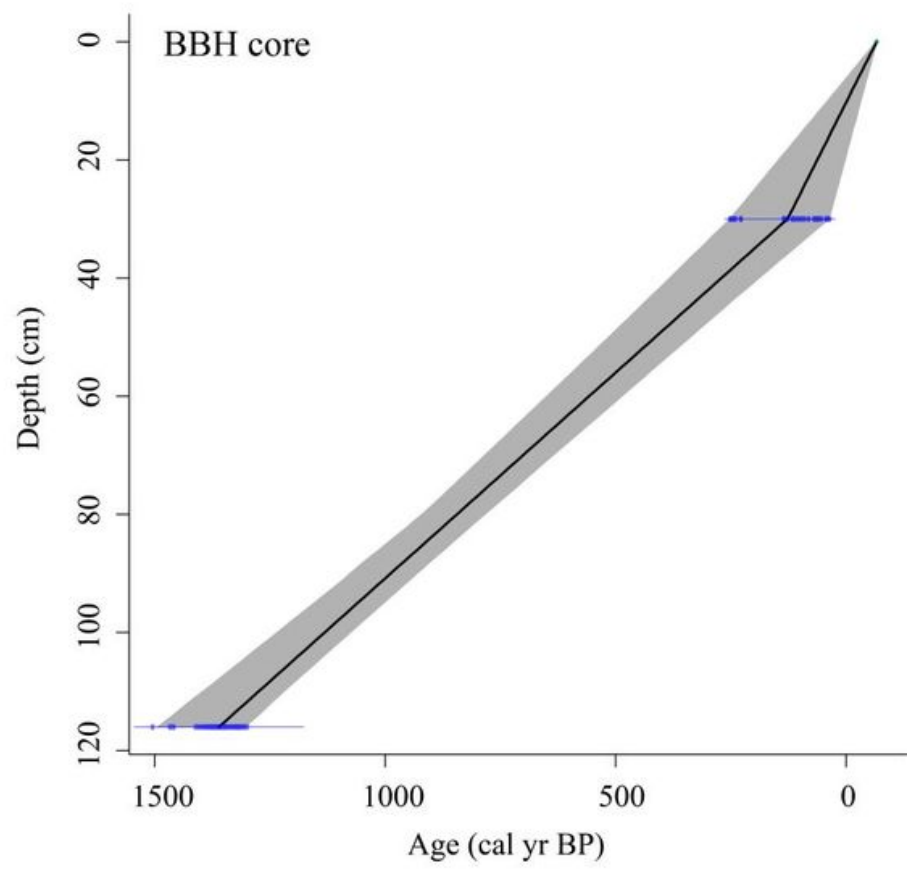

(b)

Figure 2

Age-depth model of the sediment core EYK (a) and BBH (b).

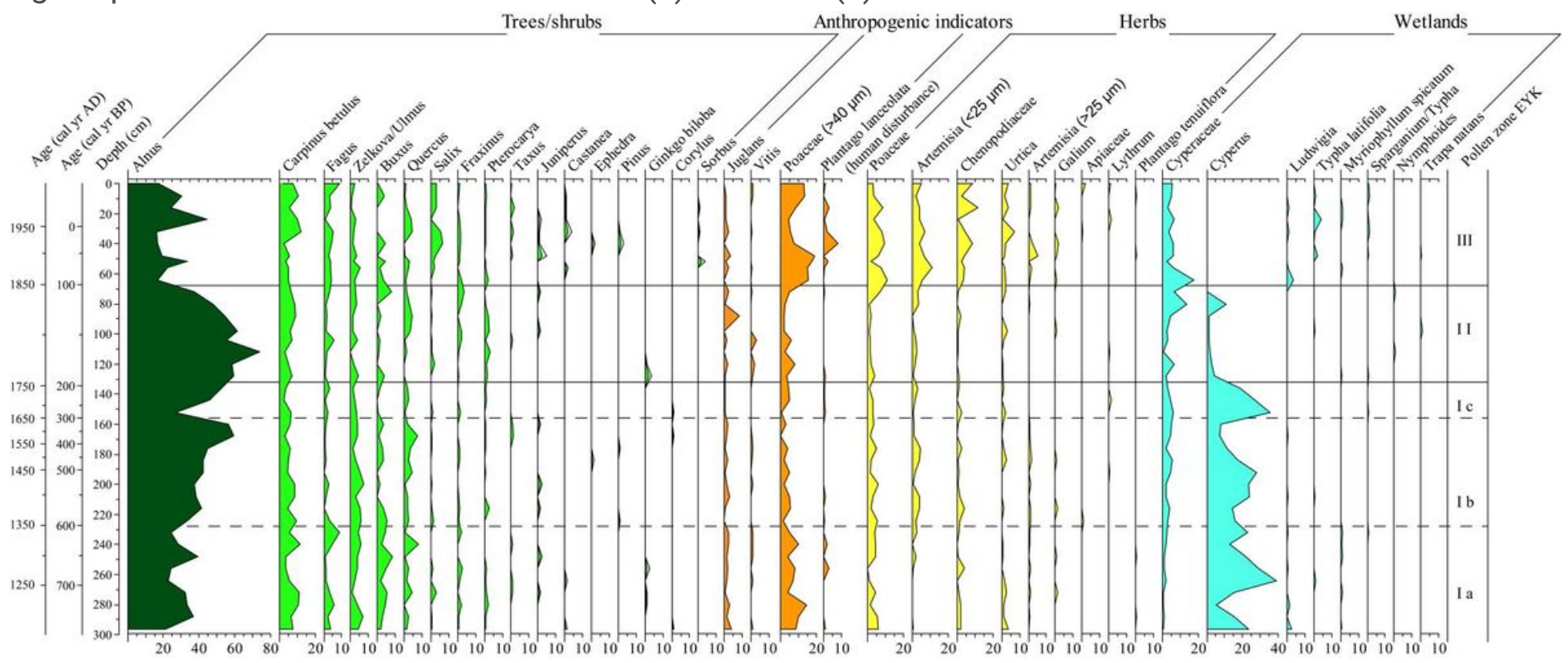

Figure 3

Pollen percentage diagram, showing the most frequent taxa of the EYK core, grouped into trees/shrubs, anthropogenic indicators, herbs, wetlands, and the pollen zones. 


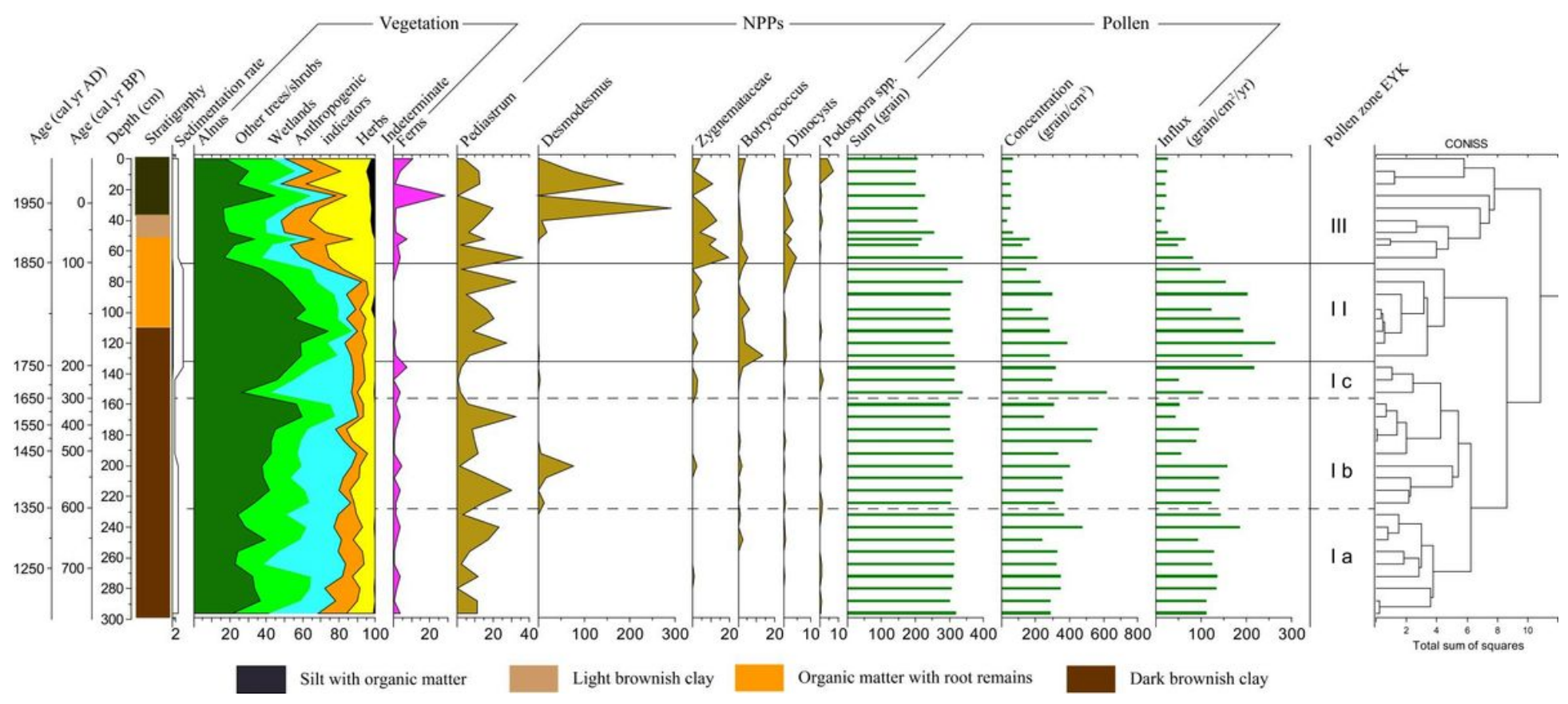

Figure 4

Summary diagram showing the stratigraphy of the sediment core, vegetation groups, ferns, NPPs, pollen sum, concentration and influx, pollen zones, the CONISS dendrogram and pollen zones of the EYK core.

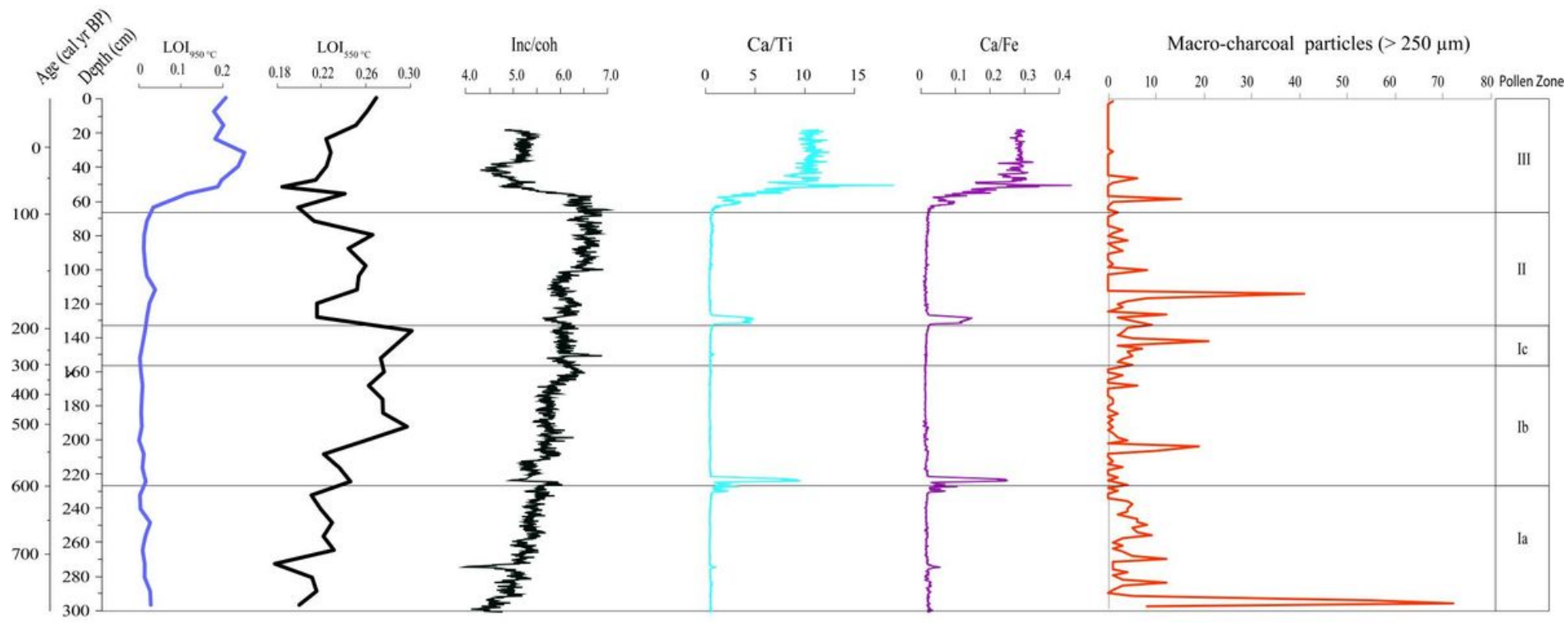

Figure 5

Diagram showing the $\mathrm{LOI} 550{ }^{\circ} \mathrm{C}$, LOI950 ${ }^{\circ} \mathrm{C}$, ratios of Inc/coh, $\mathrm{Ca} / \mathrm{Ti}, \mathrm{Ca} / \mathrm{Fe}$ of the XRF data and macrocharcoal particles of the EYK core. 


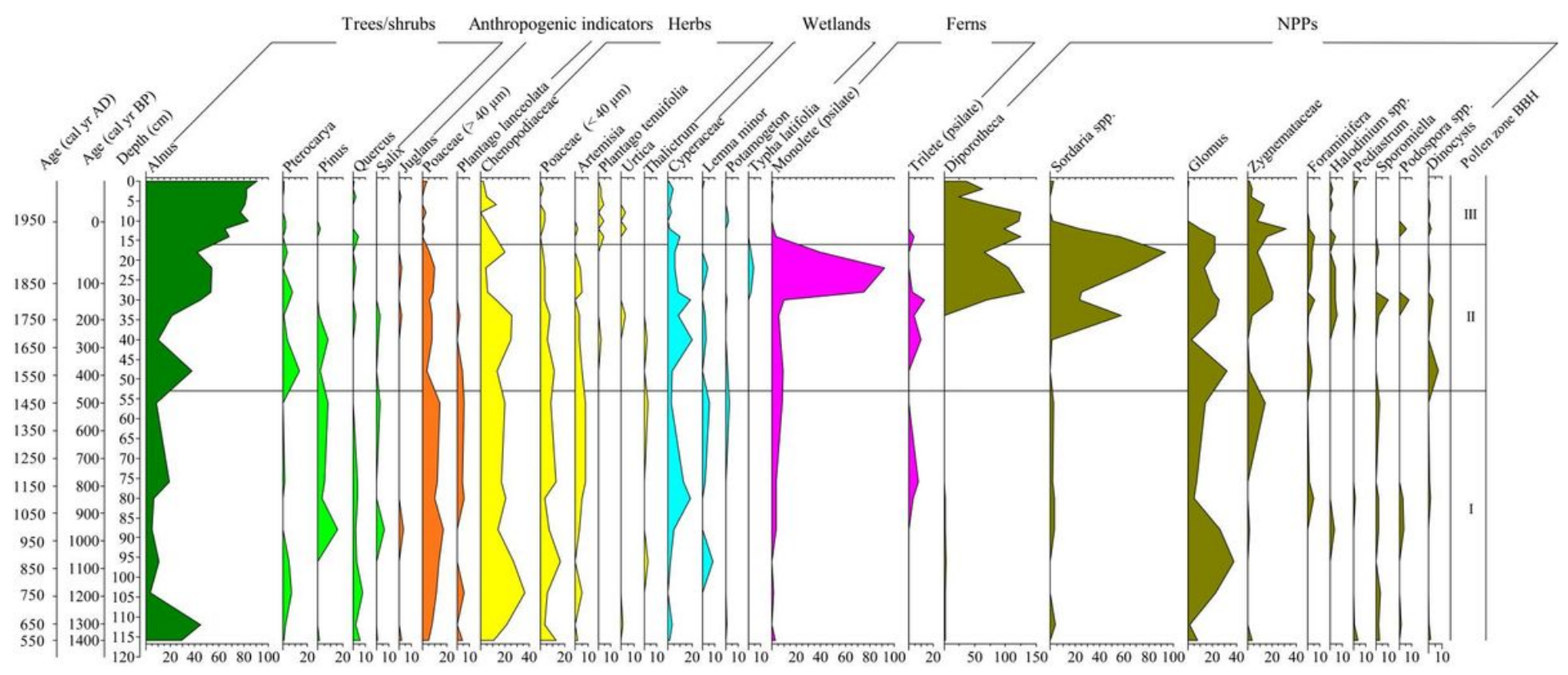

Figure 6

Pollen, spore, and NPP percentage diagram, showing the most frequent taxa of the BBH core, grouped into trees/shrubs, anthropogenic indicators, herbs, wetlands, as well as ferns and the pollen zones.

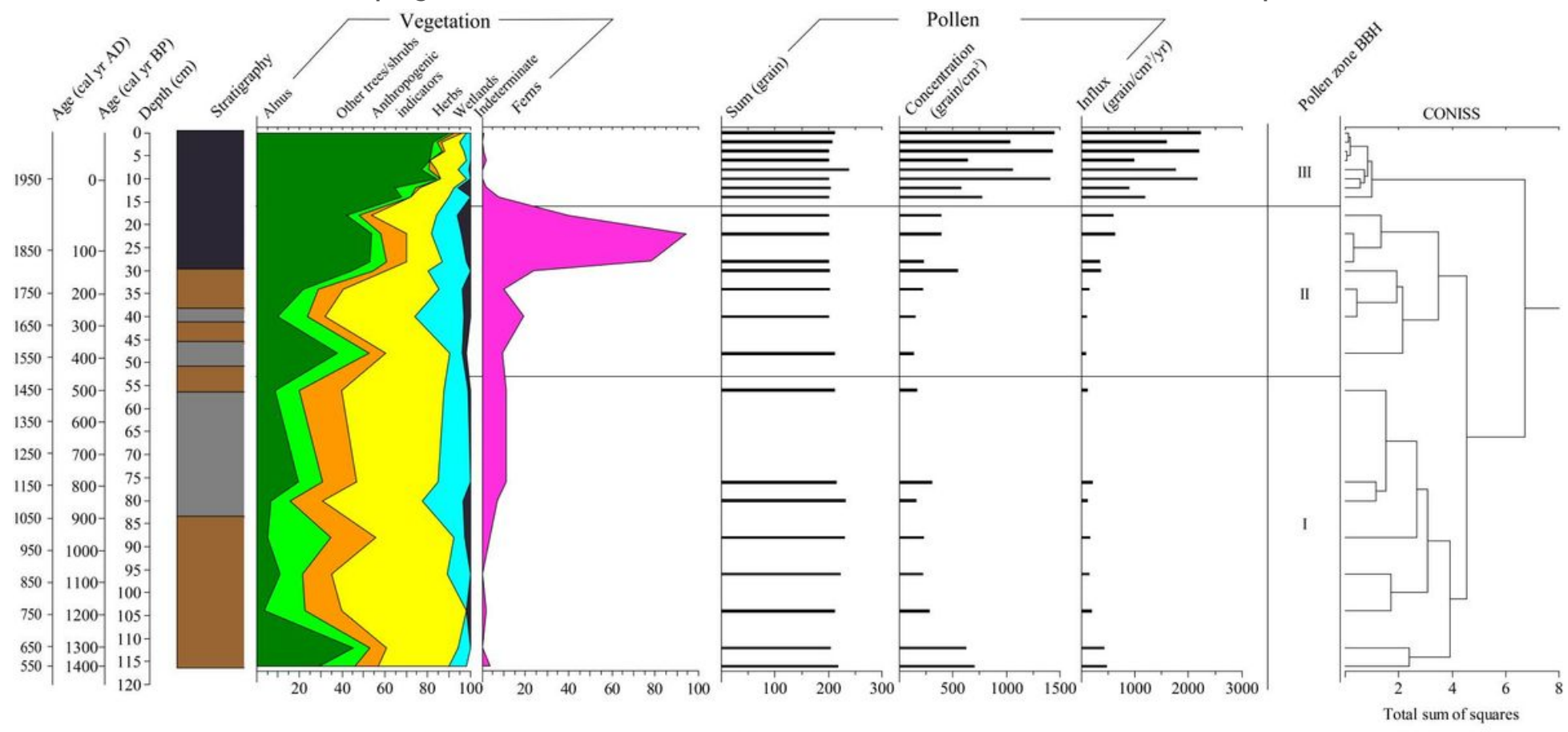

Organic matter

Clay

Sandy layer

Figure 7

Summary diagram showing the stratigraphy of the sediment core, vegetation groups, pollen count, concentration and influx, the CONISS dendrogram and pollen zones of the BBH core. 
This is a list of supplementary files associated with this preprint. Click to download.

- Table1.jpg 